\author{
I.А. Солопій ${ }^{1}$, О.І. Солонець ${ }^{2}$ Ю.О. Гордієнко ${ }^{1}$, А.О. Ткач ${ }^{1}$ \\ ${ }^{1}$ Житомирський військовий інститут ім. С.П. Корольова, Житомир \\ ${ }^{2}$ Харківський наџіональний університет Повітряних Сил ім. І. Кожедуба, Харків
}

\title{
ВИЗНАЧЕННЯ НАПРЯМКУ НА ВОГНЕВУ ПОЗИЦІЮ ПРОТИВНИКА ГРУПОЮ ЗВУКОПРИЙМАЧІВ ЗА РЕЗУЛЬТАТОМ ОБРОБКИ ДУЛОВОЇ ХВИЛІ
}

\begin{abstract}
Виявлення вогневих позиџій переднього краю противника у зоні проведення операції Об'єднаних сил залишається досить актуальною задачею. Фізичні засади застосування технічних засобів визначення вогневих позиій противника засновані на виявленні демаскуючих факторів пострілу зі стрілецької зброї, зокрема звуку від пострілу. Розробка та прийняття на озброєння акустичних систем виявлення вогневих позицій противника потребує розв'язання низки науково-практичних задач, однією з яких $є$ визначення напрямку на вогневу позичію противника за результатом обробки та аналізу дулової хвилі. В роботі запропоновано спосіб визначення напрямку на вогневу позичію противника за допомогою групи звукоприймачів. Запропонований підхід дозволяє здійснювати моніторинг певного сектору переднього краю противника в режимі часу, наближеному до реального.
\end{abstract}

Ключові слова: акустична розвідка, акустичний сигнал, виявлення вогневих позичій, група звукоприймачів, дулова хвиля.

\section{Вступ}

Постановка проблеми. Проведення антитерористичної операції та операції Об'єднаних сил (OOC) із забезпечення національної безпеки і оборони, відсічі та стримування збройної агресії Російської Федерації на території Донецької та Луганської областей викрило низку проблем, однією з яких $є$ своєчасне виявлення вогневих позицій (ВП) переднього краю противника (ПКП) - виявлення стрілецьких позицій, зокрема снайперів, мінометних позицій та ін. [1-2].

Вирішення задачі виявлення ВП може бути засноване на виявленні демаскуючих факторів зброї, основним з яких $\epsilon$ акустичний сигнал від пострілу [1-5]. За результатом обробки та аналізу акустичного сигналу від пострілу можливо визначити положення ВП та встановити тип (калібр) зброї.

У Збройних Силах (3С) України на даний час застосовуються звукометричні комплекси для виявлення місцеположення позицій артилерії [6-8]. Однак їх застосування не дає можливість викривати ВП стрілецької зброї. Акустичні засоби виявлення ВП стрілецької зброї, які широко застосовуються у ЗС передових держав світу [4-5; 9-11], на озброєнні ЗС України практично відсутні. Тому питання розробки подібних вітчизняних зразків та забезпечення ними підрозділів у зоні проведення ООС є досить нагальним.

Аналіз останніх досліджень і публікацій. Питанню виявлення ВП стрілецької зброї за результатом акустичних спостережень присвячені роботи [13; 12-13]. Існуючі системи виявлення ВП стрілецької зброї вирішують завдання за результатом оброб- ки та аналізу балістичної хвилі, генерованої прольотом кулі з надзвуковою швидкістю [4-5; 10-11]. Однак іх застосування обмежено умовою прольоту кулі не більше певної відстані від акустичної системи (акустичних сегментів засобів виявлення). Так для акустичної системи Boomerang III (США) ця відстань становить до 30 метрів [4-5]. Крім того, такі системи розраховані виключно для виявлення пострілів зі стрілецької зброї.

В роботах $[1-2 ; 12-13]$ запропоновано здійснювати виявлення ВП за результатами обробки та аналізу дулової хвилі (ДХ), що дозволяє обійти зазначені вище обмеження, в тому числі щодо виявлення будь-яких ВП ПКП. В якості одного з напрямків вирішення наведеної задачі запропоновано здійснення акустичного моніторингу ПКП противника групою звукоприймачів (ГЗП) за умови відповідної обробки акустичних даних [2].

В роботах $[2 ; 14-16]$ розглянуті деякі питання обробки вимірювальних даних ГЗП. Незважаючи на різні підходи щодо обробки акустичних даних ГЗП, загальним недоліком відомих підходів є необхідність перевірки гіпотези щодо надходження акустичного сигналу з усіх можливих напрямків, що потребує часових та обчислювальних затрат. Крім того, в умовах бойового зіткнення необхідно виключити з обробки акустичні сигнали від власних вогневих засобів.

Мета статті. Таким чином, постає актуальна науково-практична задача розробки підходу щодо визначення напрямку надходження акустичного сигналу від пострілу за допомогою ГЗП, який на відміну від відомих (існуючих) дозволить виявляти 
джерела акустичних збурень у визначеному секторі. Метою статті $є$ розробка методології визначення напрямку на ВП ПКП за результатом обробки та аналізу дулової хвилі, зареєстрованої ГЗП.

\section{Виклад основного матеріалу}

ДХ утворюється потужним звуковим імпульсом на виході каналу ствола у вигляді сферичної хвилі [12-13]. ДХ викликана виходом 3 каналу ствола газів, утворених внаслідок горіння порохового заряду, під великим тиском.

Центр цього сферичного імпульсу знаходиться трохи попереду від дульного зрізу каналу ствола. Поблизу від виходу каналу ствола швидкість ДХ дещо перевищує швидкість звуку, але вже на відстані в декілька десятків метрів ця швидкість не відрізняється від нормальної швидкості звуку, а фронт хвилі при цьому має близьку до сфери форму.

Для визначення напрямку надходження акустичного сигналу за допомогою ГЗП використовують відомий у геофізиці метод регульованого спрямованого прийому (МРСП) [16].

При використанні МРСП для всіх дискретних можливих (очікуваних) напрямків приходу акустичної хвилі проводиться перевірка гіпотез про наявність джерела акустичних збурень. Використовуючи координати умовного центру ГЗП та відносно нього положення звукоприймачів (ЗП) розраховується матриця часових затримок $\boldsymbol{T}$ розміром $k \times a$, де $k$ - кількість елементів ГЗП, $a$ - кількість напрямків, для яких проводиться процедура пошуку акустичного сигналу.

Обробка даних ГЗП з використанням МРСП проводиться шляхом затримки сигналу на виході кожного ЗП на час руху хвилі від обраного ЗП до останнього в ГЗП з відповідного напрямку, та подальшим їх складанням.

Поточне значення на виході ГЗП для обраного напрямку визначається як:

$$
s_{\alpha}(t)=\frac{1}{N} \sum_{i=1}^{N} y_{i}\left(t+\tau_{\alpha i}\right),
$$

де $y_{i}$ - елемент часового ряду, утвореного акустичним процесом, який відповідає значенню тиску на $i$-му ЗП ГЗП;

$\tau_{\alpha i}-$ елемент матриці часової затримки $\boldsymbol{T}$ на $i$-му елементі ГЗП для напрямку $\alpha$;

$N$ - кількість елементів ГЗП.

Надалі здійснюється оцінка сигналу за формулою:

$$
S_{\alpha}\left(T_{0}\right)=\frac{1}{\Delta T} \int_{T_{0}}^{T_{0}+\Delta T}\left(\frac{1}{N} \sum_{i=1}^{N}\left|y_{i}\left(T_{0}+\tau_{\alpha i}+t\right)\right|\right) d t,
$$

та оцінка шуму як:

$$
P_{\alpha}\left(T_{0}\right)=\frac{1}{\Theta} \int_{T_{0}-\Theta}^{T_{0}}\left(\frac{1}{k} \sum_{i=1}^{k}\left|y_{i}\left(T_{0}-\Theta+\tau_{\alpha i}+t\right)\right|\right) d t,
$$

де $y_{i}$ - елемент часового ряду, утвореного акустичним процесом, який відповідає значенню тиску на $i$-му ЗП ГЗП;

$\Delta T$ - найбільш ймовірний час тривалості сигнальної функції, с;

$\Theta$ - час, що передує сигналу, протягом якого оцінюється шум, с.

Відношення

$$
\Omega_{\alpha}\left(T_{0}\right)=\frac{S_{\alpha}\left(T_{0}\right)}{P_{\alpha}\left(T_{0}\right)}
$$

приймається за оцінку відношення сигнал/шум.

Показником наявності сигналу вважається перевищення порогу $\Omega_{\alpha}>h_{\Omega}$. Значення порогу становить $h_{\Omega}=2,15$ [16]. Вибір конкретного напрямку 3 усіх можливих здійснюється за максимумом оцінки сигналу за виразом (4).

Для визначення напрямку на джерело акустичних збурень виконується процедура сканування тобто перевірка гіпотези про можливе місцеположення акустичного джерела за певним напрямком.

Для практичної реалізації ГЗП та проведення експериментальних досліджень був розроблений макет акустичної системи (АC), який являє собою ГЗП з чотирьох мікрофонів, розташованих за схемою "хрест” (рис. 1). Схема проведення експерименту наведена на рис. 2.

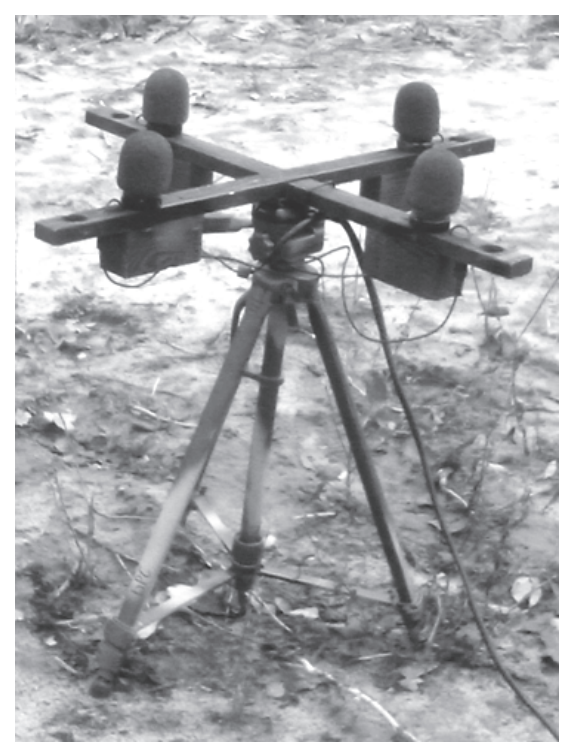

Рис. 1. Чотириканальна АC Джерело: розроблено авторами.

Сектор ведення розвідки умовного ПКП становить $80^{\circ}$. В якості джерела акустичних сигналів застосовувався піротехнічний засіб. 


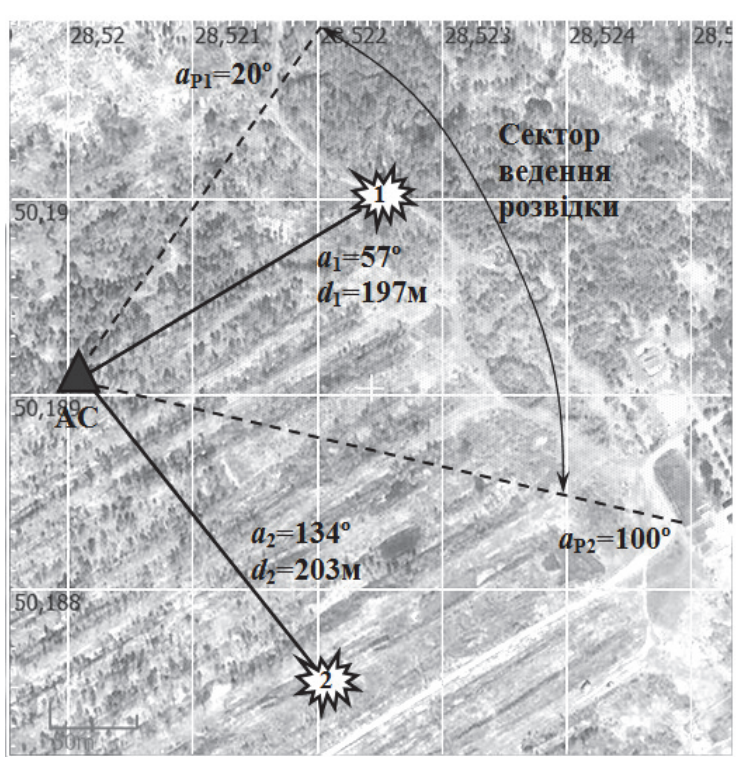

Рис. 2. Схема проведення експерименту Джерело: розроблено авторами.

На рис. 3 наведено результати застосування МРСП для обробки акустичних сигналів, зареєстрованих АC.
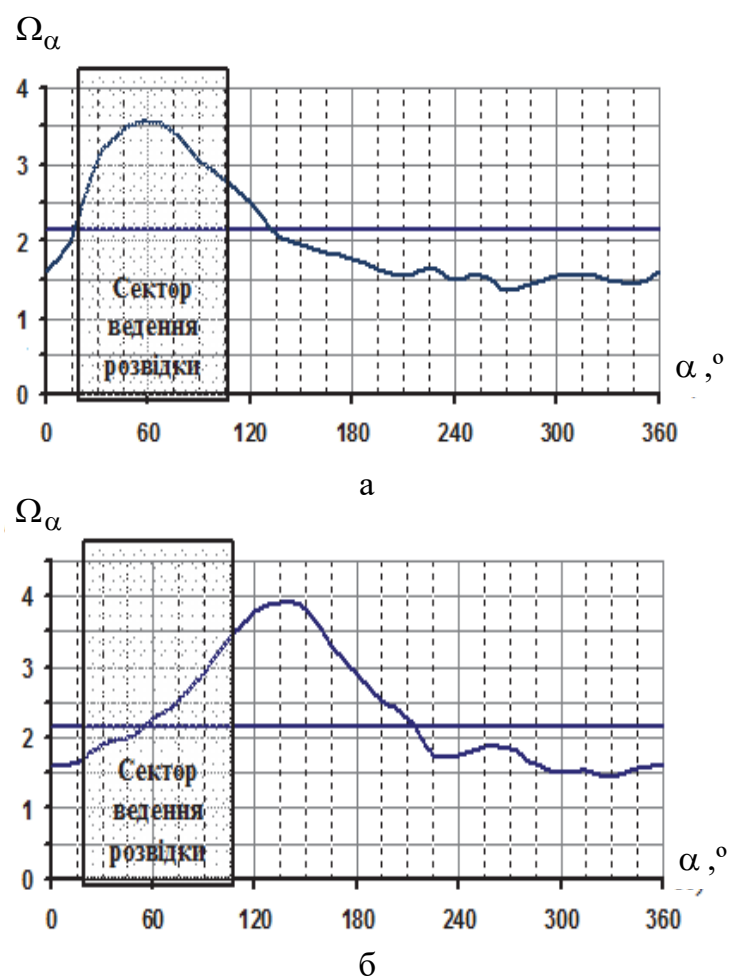

Рис. 3. Результати обробки МРСП акустичних сигналів від підриву: а-у т. $1 ; \sigma-$ у т. 2

Джерело: розроблено авторами.

Максимуми вирішальних функцій знаходяться відповідно на напрямках $57^{\circ}$ та $134^{\circ}$ і відповідають положенню точок підриву піротехнічних засобів.
Разом 3 тим, перевищення порогу для першого випадку відбувається у секторі від $27^{\circ}$ до $126^{\circ}$, у другому - від $54^{\circ}$ до $213^{\circ}$.

Як наслідок, застосування даного підходу для моніторингу ПКП (певного сектору) не виключає вплив акустичних сигналів від джерел, які знаходяться за межами сектору розвідки.

Також недоліком розглянутого методу обробки вимірювальних даних ГЗП є необхідність постійної оцінки характеристик акустичного фону та перевірки гіпотези про існування джерела акустичних збурень для всіх можливих напрямків.

Вказані недоліки можуть бути усунені шляхом застосування методу крос-кореляції (МКК). В цьому випадку сигнал, що надходить до ГЗП, являє собою стаціонарний процес в межах простору групи на невеликому інтервалі часу.

При цьому акустична хвиля $є$ плоскою когерентною, а акустичний шум не когерентний. Врахування ступеня когерентності акустичних сигналів ДХ може бути покладено в основу процесу виявлення джерела акустичних збурень за допомогою ГЗП.

Для застосування МКК ГЗП ділиться на дві підгрупи. Для кожної підгрупи хвильові форми, які зареєстровані ЗП, складаються із затримками, що відповідають певному напрямку.

Наступним кроком є оцінка функції взаємної кореляції між хвильовими формами на виході суматорів:

$$
=\frac{\int_{T_{o}}^{R_{\alpha}\left(T_{0}\right)=}}{\sqrt{\int_{T_{o}}^{T o+\Delta T} S_{\alpha}\left(T_{o}+t\right) d t} \times \sqrt{\int_{T_{o}}^{T o+\Delta T} S_{2 \alpha}^{2}\left(T_{o}+t\right) d t}}
$$

де $Z_{\alpha}(t)$ визначається як

$$
\begin{gathered}
Z_{\alpha}(t)=S_{1 \alpha}(t) \times S_{2 \alpha}(t)= \\
=\left(\frac{1}{L} \sum_{i=1}^{L} y_{i}\left(t+\tau_{i \alpha}\right)\right) \times\left(\frac{1}{L} \sum_{j=L+1}^{2 L} y_{j}\left(t+\tau_{j \alpha}\right)\right),
\end{gathered}
$$

де $S_{1 \alpha}(t)$ та $S_{2 \alpha}(t)$ - поточні значення на виході підгруп;

$$
L-\text { кількість елементів у підгрупі, } L=\frac{N}{2} \text {. }
$$

Показником наявності сигналу вважається перевищення порогу $R_{\alpha}>h_{R}$. Значення порогу в даному випадку становить $h_{R}=0,83$.

На рис. 4 наведено результати застосування запропонованого підходу для тієї ж схеми проведення експерименту (рис. 2). 


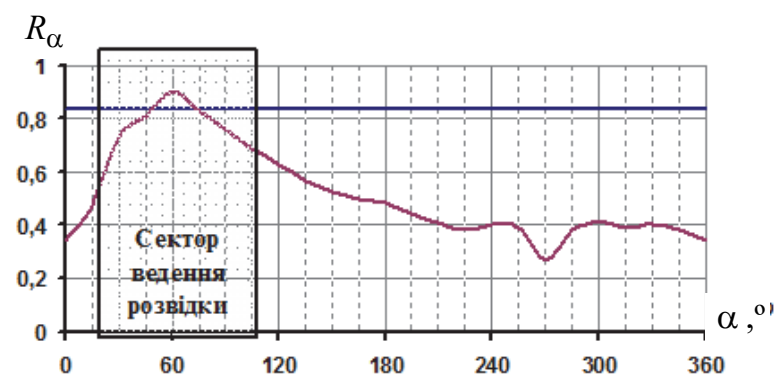

a

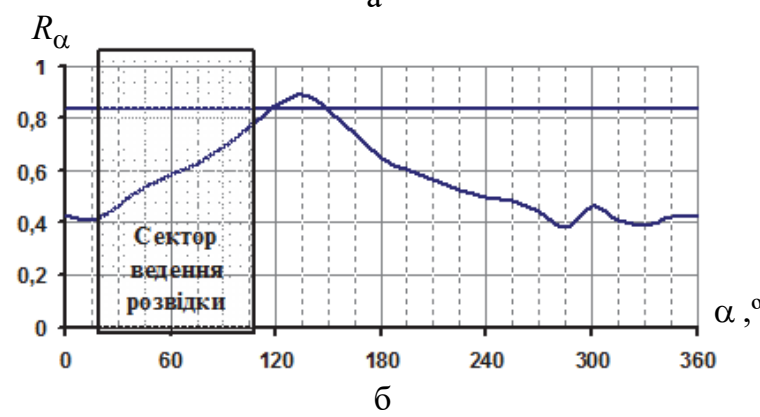

Рис. 4. Результати обробки МКК акустичних сигналів від підриву: а -у т. $1 ; 6-$ у т. 2

Джерело: розроблено авторами.

Максимуми функцій крос-кореляції знаходяться відповідно на напрямках $57^{\circ}$ та $134^{\circ}$ і відповідають положенню точок підриву піротехнічних засобів. При цьому перевищення порогу для першого випадку відбувається у секторі від $48^{\circ}$ до $73^{\circ}$, для другого - від $114^{\circ}$ до $148^{\circ}$. Таким чином, при застосуванні запропонованого способу суттєво підвищується достовірність визначення напрямку на джерело акустичного збурення у визначеному секторі розвідки.

Очевидно, що реалізація запропонованого способу обробки вимірювальних даних ГЗП для виявлення джерела акустичних збурень в межах визначеного сектору розвідки має наступні переваги:

- не потребує попередньої оцінки акустичний фон;

- виявлення та оцінка параметрів акустичних сигналів може здійснюватись досить малим числом акустичних каналів (від чотирьох включно);

- програмно-алгоритмічна реалізація обробки акустичних сигналів відносно проста;

- визначення напрямку на ВП ПКП за допомогою ГЗП може здійснюватись автоматично у режимі часу, близькому до реального.

\section{Висновки}

Експериментально підтверджені переваги способу оцінки функції взаємної кореляції між елементами групи звукоприймачів для реалізації безперервного моніторингу вогневих позицій переднього краю противника, при якому суттєво підвищується достовірність визначення напрямку на джерело акустичного збурення у визначеному секторі розвідки.

Відносна простота реалізації запропонованого підходу дозволяе визначати напрямок на вогневу позицію противника в режимі часу, наближеному до реального. Результати досліджень доцільно використати при розробці вітчизняних зразків звукометричних комплексів.

\section{Список літератури}

1. Виявлення вогневих позицій противника акустичними засобами / С.П. Фриз, Ю.О. Гордієнко, І.А. Солопій, А.О. Ткач // Матеріали X науково-практичної конференції "Пріоритетні напрямки розвитку телекомунікаційних систем та мереж спеціального призначення. Застосування підрозділів, комплексів, засобів зв’язку та автоматизації в АТО”. Київ, 9-10 листопада 2017 р. - С. 246.

2. Гордієнко Ю.О. Перспективи застосування акустичних систем виявлення пострілу / Ю.О. Гордієнко, І.А. Солопій, Р.I. Лобода // XV міжнародна наукова конференція "Новітні технології - для захисту повітряного простору”. - Харків, 10-11 квітня 2019 р. - С. 441.

3. Криворучко А.В. Дослідження основних демаскуючих ознак вогнепальної стрілецької зброї при пострілі та шляхи їх усунення / А.В. Криворучко // Сучасна спеціальна техніка. - 2009. - № 4(19). - С. 53-57.

4. Криворучко А.В. Огляд та порівняльний аналіз технічних засобів систем виявлення позиції снайпера / А.В. Криворучко // Сучасна спеціальна техніка. - 2012. - № 3(30). - С. 75-81.

5. Аналіз акустичних засобів виявлення пострілу зі стрілецької зброї та їх класифікація / Р.В. Грищук, Ю.О. Гордієнко, А.Р. Аміров, І.А. Солопій // Сучасна спеціальна техніка. - 2017. - № 3(50). - С. 103-112.

6. Кривошеєв А.М. Основи артилерійської розвідки / А.М. Кривошеєв, В.М. Петренко, А.І. Приходько. - Суми: Сумський державний університет, 2014. - 393 с.

7. Кочан Р.В. Концепція розподіленої автоматичної системи звукової артилерійської розвідки на базі стільникового зв’язку / Р.В. Кочан, Б.Р. Трембач // Сучасні інформаційні технології у сфері безпеки та оборони. - 2016. - № 1(25). C. 59-63.

8. Кочан Р.В. Методична похибка пеленгування цілі системою звукової артилерійської розвідки / Р.В. Кочан, Б.Р. Трембач, О.В. Кочан // Вимірювальна техніка та метрологія. - 2019 . - № 3(80). - С. 10-14. https://doi.org/10.23939/istemtm2019.03.010.

9. Аналіз та перспективи розвитку технічних засобів контрснайперської боротьби / О.Б. Танцюра, Я.М. Кожушко, В.В. Радецький, О.В. Шевчук // Збірник наукових праць Харківського національного університету Повітряних Сил. 2019. - № 4(62). - C. 79-84. https://doi.org/10.30748/zhups.2019.62.11. 
10. Григоров А.М. Портативные средства обнаружения огневых позиций снайперов в иностранных армиях / А.М. Григоров // Зарубежное военное обозрение. - 2012. - № 8. - С. 48-50.

11. Гейстер С.Р. Малогабаритные акустические системы обнаружения и измерения координат огневых точек / С.Р. Гейстер, Р.В. Быков // Наука и военная безопасность. - 2007. - № 1. - С. 23-27.

12. Козерук С.О. Визначення координат джерела пострілу по акустичним хвилям / С.О. Козерук, Д.В. Мазніченко // Електроніка та зв'язок. - 2017. - № 1(96). - С. 45-49. http://doi.org/10.20535/2312-1807.2017.22.1.79761.

13. Быков Р.В. Результаты экспериментальных исследований дульной волны выстрела из стрелкового оружия при однопозиционном приеме / Р.В. Быков, С.Р. Гейстер // Доклады Белорусского государственного университета информатики и радиоэлектроники. - 2012. - № 8(70). - С. 100-105.

14. Построение систем акустического группирования для реализации инфразвукового мониторинга / Ю.А. Гордиенко, Е.В. Карягин, А.И. Лящук, А.І. Солонец // Системи обробки інформації. - 2006. - № 3(52). - С. 36-42.

15. Можливість використання даних інфразвукового моніторингу під час ідентифікації природи сейсмічних подій / О.І. Лящук, Ю.А. Андрущенко, Ю.О. Гордієнко, Є.В. Карягін, І.В. Корнієнко // Геофизический журнал. - 2015. № 6(37). - C. 105-114. https://doi.org/10.24028/gzh.0203-3100.v37i6.2015.111177.

16. Обробка геофізичних сигналів у сучасних автоматизованих комплексах / М.Ф. Пічугін, О.А. Машков, В.А. Кирилюк. - Ж.: ЖВІРЕ, 2007. - 176 c.

Надійшла до редколегії 09.11.2020

Схвалена до друку 05.01.2021

\section{Відомості про авторів:}

Солопій Ігор Анатолійович старший науковий співробітник Житомирського військового інституту ім. С.П. Корольова, Житомир, Україна https://orcid.org/0000-0002-7911-0346

\section{Солонець Олексій Іванович}

кандидат технічних наук старший науковий співробітник провідний науковий співробітник

Харківського національного університету

Повітряних Сил ім. І. Кожедуба, Харків, Україна https://orcid.org/0000-0001-6223-5022

\section{Гордіснко Юрій Олексійович} кандидат технічних наук провідний науковий співробітник Житомирського військового інституту ім. С.П. Корольова, Житомир, Україна https://orcid.org/0000-0002-6141-4675

Ткач Андрій Олександрович старший викладач Житомирського військового інституту ім. С.П. Корольова, Житомир, Україна https://orcid.org/0000-0002-7983-2285

\author{
Information about the authors: \\ Igor Solopij \\ Senior Research Associate \\ of Korolov Zhytomyr \\ Military Institute, \\ Zhytomyr, Ukraine \\ https://orcid.org/0000-0002-7911-0346
}

\section{Oleksii Solonets}

Candidate of Technical Sciences Senior Research

Lead Research

of Ivan Kozhedub Kharkiv

National Air Force University,

Kharkiv, Ukraine

https://orcid.org/0000-0001-6223-5022

Yurii Gordiienko

Candidate of Technical Sciences

Lead Research

of Korolov Zhytomyr

Military Institute,

Zhytomyr, Ukraine

https://orcid.org/0000-0002-6141-4675

\author{
Andrii Tkach \\ Senior Instructor \\ of Korolov Zhytomyr \\ Military Institute, \\ Zhytomyr, Ukraine \\ https://orcid.org/0000-0002-7983-2285
}

\section{ОПРЕДЕЛЕНИЕ НАПРАВЛЕНИЯ НА ОГНЕВУЮ ПОЗИЦИЮ ПРОТИВНИКА ГРУППОЙ ЗВУКОПРИЕМНИКОВ ПО РЕЗУЛЬТАТАМ ОБРАБОТКИ ДУЛЬНОЙ ВОЛНЫ}

И.А. Солопий, А.И. Солонец, Ю.А. Гордиенко, А.А. Ткач

Обнаружение огневых позиџий переднего края противника в зоне проведения операџии Объединенных сил остается достаточно актуальной задачей. Физические основы применения технических средств определения огневых позиций противника основаны на обнаружении демаскирующих факторов выстрела из стрелкового оружия, в частности звука от выстрела. Разработка и принятие на вооружение акустических систем обнаружения огневых позиций противника требует решения ряда научно-практических задач, одной из которых есть определение направления на огневую позицию противника по результатам обработки и анализа дульной волны. В работе предложен способ определения направления на огневую позицию противника с помощью группы звукоприемников. Предложенный подход позволяет осуществлять мониторинг определенного сектора переднего края противника в режиме времени, приближенном к реальному.

Ключевые слова: акустическая разведка, акустический сигнал, обнаружение огневых позиций, группа звукоприемников, дульная волна. 
DETERMINATION OF THE DIRECTION TO THE ENEMY FIRING POSITION BY A GROUP OF SOUND RECEIVERS ON THE RESULT OF THE MUZZLE BLAST PROCESSING

I. Solopij, O. Solonets, Yu. Gordienko, A. Tkach

Detection of firing positions of the enemy's front line in the area of the Joint Forces operation in Eastern Ukraine is an urgent task. To solve this problem it is necessary to develop technical means for detecting firing positions of the enemy front line and determining their coordinates for rapid targeting and application of destruction means. Physical principles of application of technical means for enemy firing positions determination are based on revealing of unmasking factors of a shot from small arms, in particular a sound from a shot. The priority of the use of acoustic means for detecting enemy firing positions is explained by the relative simplicity of their technical implementation, maintenance and low cost. To develop and adopt acoustic systems for detecting enemy firing positions it is necessary to solve a number of scientific and practical problems, one of which is determination of the direction to the enemy firing position by processing and analysis of the muzzle blast. The paper suggests a method for determining the direction of the enemy firing position by using a group of sound receivers. The aim of the article is to develop a methodology for determining the direction to the firing position of the enemy front edge on the basis of processing and analysis of the muzzle blast registered by a group of sound receivers. The suggested approach, in contrast to the known ones, allows for acoustic monitoring of a certain sector (areas of the front edge of the enemy), excluding the impact of sources of acoustic disturbances from other areas. The relative simplicity of the suggested approach allows to determine the direction of the enemy's firing position almost in a real-time mode. To process the muzzle blast registered by a group of sound receivers, the cross-correlation method is used. At it the group of sound receivers is divided into two subgroups. For each subgroup, the registered waveforms are added to the delays corresponding to a certain direction, and then the cross-correlation function is estimated. The suggested method significantly increases the reliability of determining the direction to the source of acoustic disturbance in a given sector of reconnaissance. The advantages of the suggested method are confirmed experimentally.

Keywords: acoustic reconnaissance, acoustic signal, detection of firing positions, group of sound receivers, muzzle blast. 